\title{
Sustainable Biodiesel Reactor Prototype Energetically Powered By Solar Energy
}

\author{
Fabiano Almeida Nascimento ${ }^{1}$, Luiz Antônio Pimentel Cavalcanti ${ }^{2}$ \\ ${ }^{1}$ (Electrical Engineering Department, Federal Institute of Bahia, Brazil) \\ ${ }^{2}$ (Academic Department, Federal Institute of Bahia, Brazil)
}

\begin{abstract}
The study of routes aiming the implementation and use alternative energy sources has increased exponentially during the last decades, due to reduction of petroleum reserves and environmental damage related to fossil fuels use. In this context, biodiesel appears as a potential substitute for diesel, however, because of its economic non-competitiveness, there is still an obstacle to a greater use of this fuel. Alternatives for operational costs reduction on biodiesel production process, most commonly carried out by methyl transesterification, rely on solar energy use to generate electricity and obtain heat for chemical reaction needs. This work presents the design, dimension and construction process of a sustainable biodiesel reactor powered energetically by a solar collector constructed with recycled materials, such as polyethylene terephthalate (PET) bottles, and electrically powered by a photovoltaic system. The solar radiation and photovoltaic study was made considering the electrical consumption forecast. Tests were carried out to verify the chemical reaction heat transfer and the electric circuit operation in order to verify the prototype reliability. The final product was evaluated using gas chromatography technique showing that the produced biodiesel presented $97.6 \%$ in ester contents, bigger value than the recommended by European Committee for Standardization and the Brazilian National Agency of Petroleum, Natural Gas and Biofuels (ANP).

Keywords: Biodiesel, Photovoltaic Energy, Solar collector, Recycling, Cost Reduction
\end{abstract}

\section{Introduction}

Portion of the consumed energy in the world is demanded by population and industry that uses as main primary source the petroleum, natural gas and mineral coal. The intensive use of such sources is associated with environmental, economic and social impacts. Therefore, there is a great encouragement by the scientific community to seek production and use ways for biofuels and other energy sources in order to increase the energy mix through the use of renewable sources, minimizing the environmental damages already caused by fossil fuels [1].

In this context, biodiesel appears as a potential substitute for petroleum derivatives because it has renewable, biodegradable and non-toxic characteristic, which is capable of emitting almost irrelevant amounts of sulfur compounds during its combustion. Programs to encourage the production and use of biofuels have been implemented in several countries during the last decades, increasing the need for improvement and efficiency growth of their production processes so it can become not only environmentally sustainable but also economically viable [2].

Biodiesel can be obtained through three distinct routes: cracking, esterification and transesterification. In Brazil, this biofuel is usually obtained through homogeneous alkaline transesterification, which requires oil with food refinement level, what increases the final product cost, decreasing its competitiveness in relation to fossil origin diesel. In order to reduce production costs, it is necessary to resort to the use of unrefined biomass (Residual Oils and Fats - ROFs) and alternative/cheaper energy sources to supply energy demands [3].

The transesterification process presents yield gain when reactants are stirred and heated during the chemical reaction, in a temperature range between $40^{\circ} \mathrm{C}$ and $50^{\circ} \mathrm{C}$. These increasing efficiency strategies bring the increasing of process overall cost and, consequently, the final product costs, since both processes of heating and stirring requires, respectively, thermal and electrical energy to occur [4].

Being the sun the largest source of primary energy available on planet, searching for more efficient and cheap ways to use and convert energy delivered by solar rays is increasing and the cheaper technologies applicable to these purposes gets the most popular it becomes for uses that aims costs decreasing and environmental gain in the generation of electric and thermal energy [5].

An alternative proposal to electric resistances use for heating transesterification reaction is the use of solar collectors to supply the thermal energy demand of this process; it can reduce operation costs and environment impact. The proposal proved to be feasible at the point that the reaction temperature reached the desired values and biodiesel production occurred with a percentage of $97.1 \%$ of fatty acid methyl esters (FAME), higher than the $96.5 \%$ indicated both by European Committee for Standardization at EN 14214 and by Brazilian National Agency of Petroleum, Natural Gas and Biofuels (ANP) as desirable. [4]. 
This work aimed to design, build and evaluate the efficiency and effectiveness of a reactor for biodiesel production composed of a sustainable heating system, by using a solar collector made with recyclable materials, and a photovoltaic system, aiming to supply all the energy demands of the homogeneous alkaline transesterification process through renewable energy sources and analyse the possibility of application in larger scale.

\section{Materials And Methods}

The needed components and equipment to construct the whole biodiesel production system were evaluated, planning the types of materials needed to build the subsystem modules to reduce the overall cost of biodiesel production process. The following subsystems were defined:

- Heating System;

- $\quad$ Stirring System;

- $\quad$ Electrical Power System;

- $\quad$ Pumping System;

- $\quad$ Stirring speed control System;

\subsection{Materials}

In Table 1, the materials used at the construction of the entire prototype system and the situation of obtaining them are exposed.

Table 1- Material, quantities and situation of obtaining for biodiesel production prototype construction

\begin{tabular}{|c|c|c|}
\hline Material & Quantity & Situation \\
\hline 2 litters PET bottles & 06 Unities & Renewable \\
\hline PVC Pipe $1 / 2$ inch & 05 Meters & New \\
\hline Tetra Pak milk package & 06 Unities & Renewable \\
\hline Transparent Hose & 02 Meters & New \\
\hline AC Pump 127V 0,75W & 01 Unity & Renewable \\
\hline Electrical Motor AC $127 \mathrm{~V} 40 \mathrm{~W}$ & 01 Unity & Renewable \\
\hline 20 Litters Bucket & 01 Unity & Renewable \\
\hline PVC Pipe Connections (Knee type) & 06 Unities & New \\
\hline PVC Pipe Connections ("T" type) & 06 Unities & New \\
\hline Batteries 45Ah & 02 Unities & Renewable \\
\hline Photovoltaic Panel 50Wp 14,4V & 01 Unity & New \\
\hline Charge Controller 12V 10A & 01 Unity & New \\
\hline $\begin{array}{l}\text { Frequency } \\
12 \mathrm{~V} / 127 \mathrm{~V}\end{array} \quad$ inverter $\quad$ CC/CA $\quad 400 \mathrm{~W}$ & 01 Unity & New \\
\hline Electrical wires $6 \mathrm{~mm}$ & 10 Meters & Renewable \\
\hline
\end{tabular}

\subsection{Solar Collector}

The homogeneous alkaline transesterification reaction generally requires heated water circulation through the reactor walls. Seeking the technical feasibility, economic gain and availability of obtaining materials, it was decided that the heating system would be composed by a sustainable solar collector based on the "Manual for Construction and Installation of a Solar Heater Made with Recyclables" [6], consisting basically of PET bottles, Tetra Pak milk packages and PVC pipes, painted in mat black. The heating system dimensioning was based on the forecast of prototype nominal biodiesel production.

At the end of the prototype construction, temperature variation of the projected volume of water, to be heated by the solar collector, was measured at 15 minute intervals while the system was exposed to the sun, aiming to determine if the amount of heat absorbed by the collector would be sufficient to meet the process energy demands.

\subsection{Photovoltaic Power System}

The solar and photovoltaic study was based on the information contained in the "Engineering Manual for Photovoltaic Systems of the Solar and Wind Energy Center Sérgio de Salvo Brito" (CRESESB) and Center for Electric Energy Research (CEPHO) [7], taking into account the forecast consumption of electrical equipment. The electric power values of the equipment to be used were surveyed and a projection of the consumption in Wh made for the entire biodiesel production process, this being, therefore, the minimum power of the photovoltaic system. The amount of batteries (considering 12 hours of autonomy) used was defined considering the nominal power consumption $(40,75 \mathrm{~W})$ and the time of a biodiesel batch production (1 hour per batch / 12 batch day). Fig. 1 shows the prototype electric assembly scheme. 


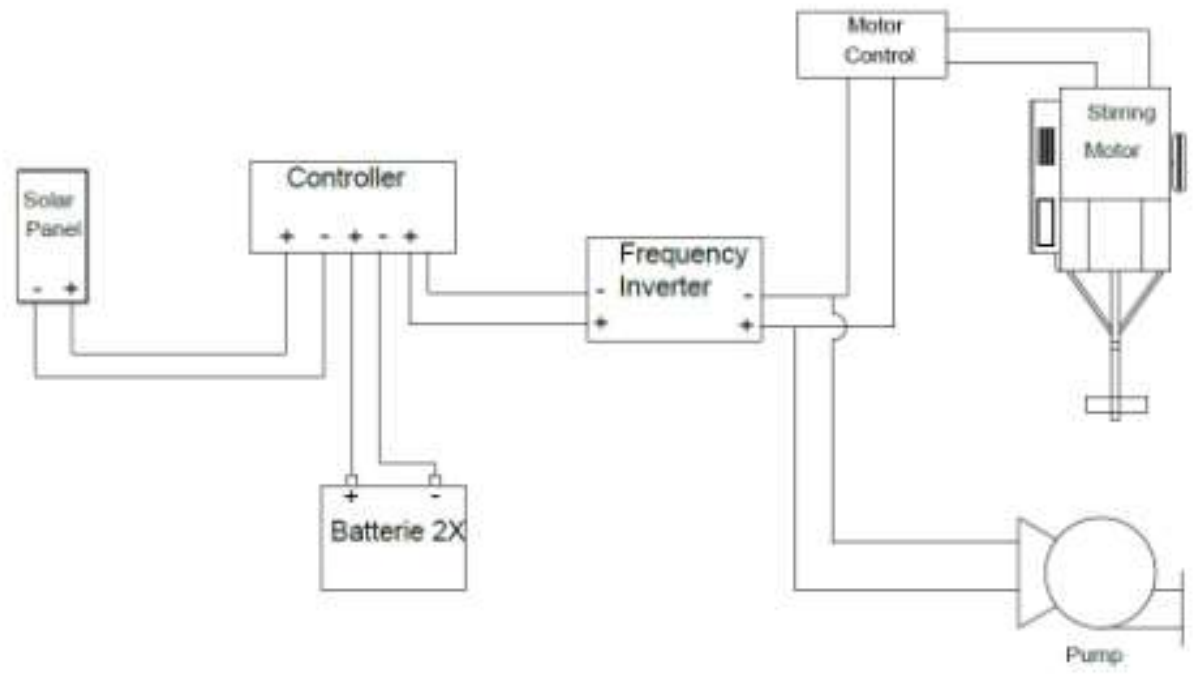

Figure 1 - Prototype electric assembly scheme

\subsection{SUSTAinable Reactor}

The reactor equipped with a stirring system, shown in Fig. 2, was designed from the text-based orientations on specialized literature [8] and was assembled from waste materials coming from civil construction in addition to a fan motor, a bearing and a glass vessel. The electrical power system was made based on an isolated photovoltaic system and the pumping system mounted with a reused washing machine pump. The stirring speed control was designed from an AC voltage variation circuit basically composed of a DIAC and a TRIAC, according to Fig. 3.

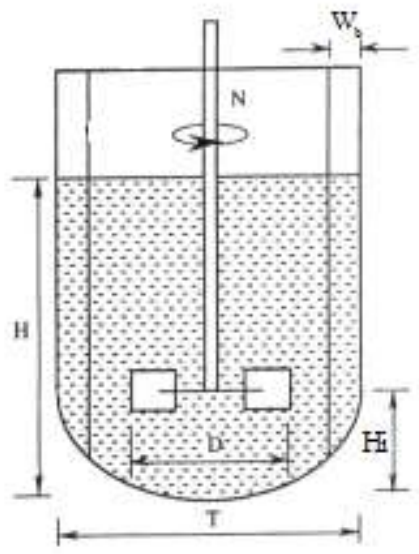

- $\mathrm{T}=13 \mathrm{~cm}$

- $\mathrm{H}=13 \mathrm{~cm}$

- $\mathrm{D}=4,33 \mathrm{~cm}$

- $\mathrm{Hi}=4,33 \mathrm{~cm}$

- $\mathrm{Wb}=1,3 \mathrm{~cm}$

Figure 2 - Reactor with stirring system

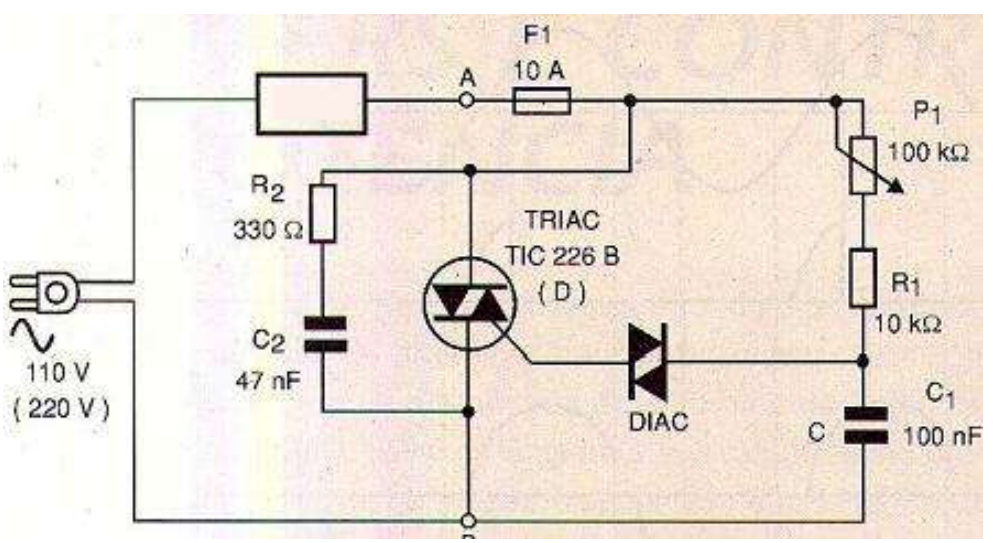

Figure 3 - AC voltage variation circuit to control stirring speed. 


\subsection{Biodiesel Production}

B100 derived from soybean oil, $2.2 \mathrm{~L}$, was produced by homogeneous alkaline transesterification reaction (catalyst: potassium methoxide, $1 \% \mathrm{w} / \mathrm{w}$, relative to the oil mass). The chemical reactor was a glass vessel, as previously described, immersed in a $20 \mathrm{~L}$ barrel adapted to function as a jacketed reactor, in which was circulating water from the solar collector. The reaction temperature was measured by using a digital thermometer immersed in the reactor where the transesterification reaction was taking place, and the mechanical stirring was obtained with the aid of a bladed impeller designed as shown in Fig. 2. The operational conditions on these stages were: a) temperature: $50{ }^{\circ} \mathrm{C}$; B) pressure: $1 \mathrm{~atm}$; C) rotation of the mechanical stirrer: $300 \mathrm{rpm}$; D) alcohol / oil molar ratio: 6 to 1; And e) reaction time: $1 \mathrm{~h}$. At the end of the reaction batch, the glycerin was separated from the reaction mixture with the aid of a decantation funnel. The lighter phase of the mixture containing B100, catalyst and methanol excess - went through the purification stage: consisting of acid wash with $0.5 \mathrm{M}$ hydrochloric acid solution and the other washes that were performed with distilled water, aiming the $\mathrm{PH}$ adjustment of the produced biodiesel.

The biodiesel drying was carried out in a rotary evaporator with vertical glass brand IKA, model RV10. An economic and reliability system superficial analysis was made with the parameters available to observe the economic gains of biodiesel production with the prototype when compared to conventional systems.

\subsection{Biodiesel Chemical COMPOSITION ANALYSIS}

The produced biodiesel chemical composition was analyzed by gas chromatography with a Ciola Gregory brand; model CG Master, Carbowax column (dimension $30.0 \mathrm{~m}$ in length, $5.3 \times 10^{-4} \mathrm{~m}$ in internal diameter and thickness. Hydrogen (White Martins $\geq 99.99 \%$ ) was used as the eluent. The FAME standards were purchased from Sigma-Aldrich. The composition of ester content in the produced biodiesel was also determined by gas chromatography.

\section{Results And Discussion}

The optimum positioning for the solar collector and the photovoltaic panel according to the sun was done as described at "Manual for Construction and Installation of a Solar Heater Made with Recyclables" CELESC [6]. In Paulo Afonso city, Bahia State, where the tests in the prototype were carried out, the geographical localization is at coordinates $09^{\circ} 24$ '22"S and $38^{\circ} 12$ '53 "W. This geographic location is fundamental for determining the inclination of the solar panel and the solar collector, which must be equal, in degrees, to the latitude of the place where the prototype is installed (about $10^{\circ}$ in this case). Still according to the aforementioned Manual, solar photovoltaic panel inclination should be to the north, in view of the relative sun movement and the inclination of the earth in relation to its own axis.

The batteries dimensioning used in the isolated photovoltaic system and the photovoltaic solar panel itself was based on a research about the time for biodiesel production - one hour per batch and a desired system autonomy of 12 hours - and the power of the electrical equipment used in the prototype: Pump and stirrer motor $40,75 \mathrm{~W}$ in total. The photovoltaic system load controller shall comply with a maximum operating current of $3.5 \mathrm{~A}$ and an operating voltage of $12 \mathrm{~V}$ considering the nominal electrical power generation of the PV panel. The total power of the system and the DC / AC inverter shall meet the maximum power of 40,75W. Considering the maximum operating current and the desired range, two $45 \mathrm{Ah}$ batteries are sufficient for the system. The physical structure of the prototype after assembly is shown in Fig. 4.

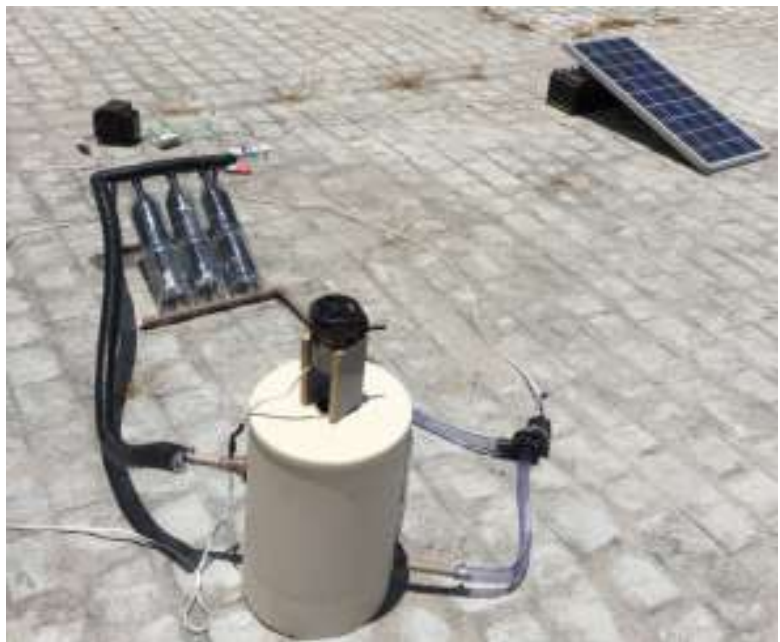

Figure 4 - Prototype assembled and ready for tests. 
Solar collector was installed in the courtyard of the biofuels building at the Federal Institute of Bahia (IFBA), located in Paulo Afonso city, Bahia - Brazil. Temperature values from the water heated by the solar collector were evaluated in the morning because it is the critical system operation period, due to the lowest incidence of solar rays / power and consequently lower water temperature, due to the cooling during night. On this way, enough heat collection for reaction will be guaranteed in the afternoon due to the longest exposure to the sun and higher solar power / rays incidence. The analysis indicated that at 9 o'clock in the morning, when the prototype is under a clear sky condition, the temperature measured was $40^{\circ} \mathrm{C}$ and the highest temperature in the

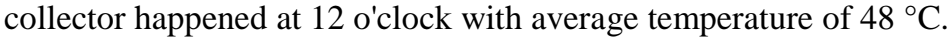

Methyl biodiesel production can be carried out in a temperature range between 30 and $50{ }^{\circ} \mathrm{C}$. After studying solar energy and carrying out tests at the sustainable solar collector prototype, it was observed that the system operation presents a fast gain of energy, especially in the periods with more solar radiation, with a considerable increase of the temperature in the first 30 minutes of solar exposition - about $20^{\circ} \mathrm{C}$. It was possible to note that the use of this technology for heating the transesterification reaction would be successful, because this reaction happens with a minimum temperature turning around $30{ }^{\circ} \mathrm{C}$ [4].

Transesterification reaction started when the collector had a temperature of $51^{\circ} \mathrm{C}$. In this work the attention is focused mainly on ester content, since the objective was to construct a collector capable of performing the transesterification reaction satisfactorily. Therefore, others parameters cited in ANP Resolution 45 [9] and EN 14214 [10] were not relevant to this research. Fig. 5 shows the prototype in an electric and functional scheme positioned according to real application. Fig. 6 shows the separation process between biodiesel and glycerin that characterizes the beginning of the biofuel purification process.

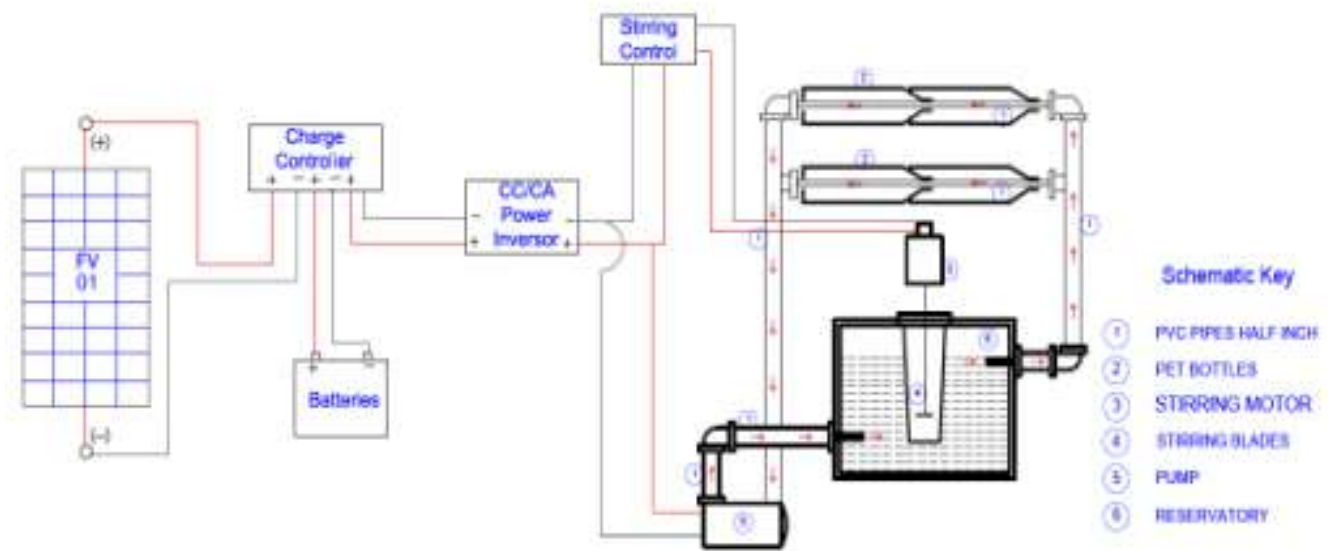

Figure 5 - Schematic of system arrangement.
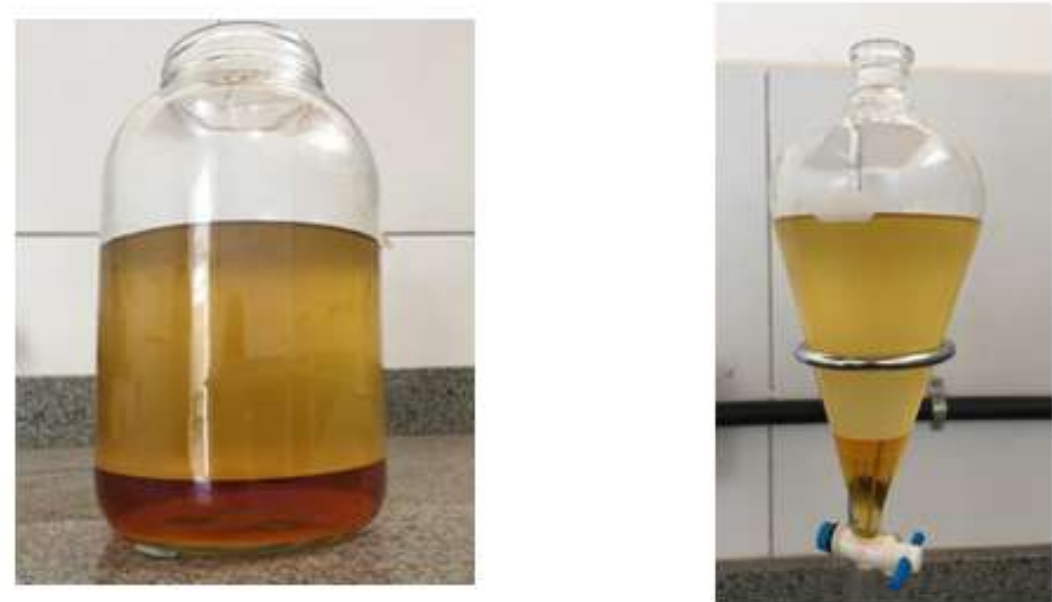

Figure 6 - Separation between produced biodiesel and glycerin.

The first biodiesel production batch was done by following the methodology presented in section 2.5 and the final product was evaluated by using gas chromatography technique, which showed that the biodiesel presented yield in terms of the ester content of 97.6\%, superior result than that recommended by ANP and European Committee for Standardization in Resolution No.45/2014 and EN 14214 respectively, which is $96.5 \%$. 
Table 2 shows the content of fatty acid methyl esters (FAME) present on the produced biodiesel. When evaluating chromatographic results at the profile of soybean biodiesel related to fatty acids contents, it was verified that $29.74 \%$ of the fatty acids are saturated and $70.26 \%$ are unsaturated. These values are in agreement with those published by [11] low point of mist and fluidity, which can be used in places with cold climates.

The values presented in Table 2 are considered satisfactory with respect to B100-S, since such values are close to those found in [4]. The ester content observed at B100-S produced had a value of 97.6\%. ANP Resolution Number 45/2014 [9] and EN 14214 standard [10] specifies minimum ester content in biodiesel of 96.5\%.Therefore it can be stated that the result of biodiesel production in relation to the ester content was satisfactory, once the results founded are according to ANP and EN Resolution.

Table 2- Content of fatty acid methyl esters presented on the produced biodiesel.

\begin{tabular}{|l|l|l|l|l|l|}
\hline B100-S & Unsaturated \\
\hline \multirow{2}{*}{ FAME } & Saturated & C18:0 & C18:1 & C18:2 & C18:3 \\
\cline { 2 - 6 } & C16:0 & 7,31 & 15,98 & 51,07 & 3,21 \\
\hline Content (\%) & 22,43 & &
\end{tabular}

The prototype attests that biodiesel production can be electrically and thermally powered with a sustainable and low cost system, using solar energy to provide the system sufficient heat levels for the good performance of the transesterification reaction.

\section{Conclusion}

The prototype conclusion and the subsequent biodiesel production with it showed that it was possible to supply the heat energy demand for transesterification reaction with a low budget sustainable collector constructed from recycled materials. Recycled materials behaved satisfactorily during all tests.

The photovoltaic system dimensioned and used during the experiment was enough to supply the electrical system demands during one batch and the electric circuit designed and used presented high reliability during the biodiesel production process.

Produced Biodiesel presented satisfactory performance in terms of ester content which was $97.6 \%$ for the first test.

Sustainable biodiesel production system proved to be highly reliable and did not present clear impediments that could preclude system replication on a larger scale, presenting lower implantation and maintenance costs.

\section{Acknowledgements}

This research was supported by Brazilian National Counsel of Technological and Scientific Development (CNPq). We thank Federal Institute of Bahia by providing equipment and working space for this project.

\section{References}

[1] P. Kemerich, et al, Paradigmas Da Energia Solar No Brasil E No Mundo, Revista Eletrônica Em Gestão, Educação E Tecnologia Ambiental, 20, 2016, 241-247.

[2] L. Ramos, Tecnologias de Produção de Biodiesel, Revista Virtual de Química, 3, 2011, 385-405.

[3] C. Elicker, Estudo Da Utilização Da Biomassa De Cianobactérias Como Matéria-Prima Para A Síntese De Biodiesel Através Da Reação De Esterificação In Situ, Revista Virtual de Química, 7(6), 2015, 2497-2508.

[4] L. Cavalcanti, Produção de Biodiesel Metílico de Soja com o Auxílio de um Coletor Solar Sustentável, Revista Principia Divulgação Científica e Tecnológica da UFPB, S1., 2016, 105-109.

[5] M. L. R. Shuck, Coletor Solar Para Pré-Aquecimento Do Ar Em Sistemas De Secagem, Estudo De Caso - Cura Do Tabaco, Master diss., Universidade Federal de Santa Maria, Santa Maria, SC, 2012.

[6] J. A. Alano, Manual do Aquecedor Solar - Aquecedor solar composto de produtos descartáveis: Manual de construção e instalação, Celesc Distribuição S.A., 2009

[7] J. T. Pinho and M. A. Galdino, Manual de engenharia para sistemas fotovoltaicos. CRESESB - CEPEL, 2014.

[8] A. Foust, Princípio das Operações Unitárias, RJ: LTC, 1982.

[9] Agência Nacional do Petróleo, Gás Natural e Biocombustíveis (ANP), Resolução Número 45, de 25 de agosto de 2014, available at <http://nxt.anp.gov.br/NXT/gateway. dl1/leg/resolucoes_anp/2014/agosto/ranp 45 - 2014.xml>., access in 01 March 2017.

[10] European Committee for Standardization. EN 14214: Automotive fuels - Fatty acid methyl esters (FAME) for diesel engines Requirements and test methods. 2003.

[11] G. Knothe, J. V. Gerpen, L. P. Ramos. Manual do Biodiesel, SP: Edgard Blucher, 2006. 